\title{
The Early Plays of George Bernard Shaw: An Analysis
}

\author{
Dr. C. S. Srinivas \\ Assistant Professor of English, Mahatma Gandhi Institute of Technology, Gandipet \\ Hyderabad 500075India
}

I. Introduction

George Bernard Shaw appeared on the literary scene when a great change took place in English drama with the arrival of Ibsen on the English stage. The new shift towards various social problems given to English drama by the innovators like A. W. Pinero, T. W. Robertson, and Henry Arthur Jones received immense support from Ibsen, whose plays aroused great interest in England by the shocking novelty of their themes. Shaw, well known for his hawk-eyed observation, took notice of the new changes and most effectively expressed them through his creative and critical works. In this way, he began his career as an exponent of realism and as a determined inculcator of the play of ideas and became the first English dramatist to use the stage as a platform for social propaganda.

Shaw strongly felt that the preoccupation of a dramatist was with the conflict between human feelings and circumstances, every social question furnishing material for drama. He was predominantly a socialist who only who only believed in equality as the sane, possible basis of social organization and manners. In this sense, Shaw was a rationalist as well. C.E.M. Joad observes, "Truth being clear, close and communicable, the most obvious method of communication is that of exposition and demonstration. Hence Shaw is predominantly a rationalist."(60)

Shaw's early plays are classified - "Plays Unpleasant" Widower's Houses (1892), The Philanderer (1893), Mrs. Warren's Profession (1893-94), "Plays Pleasant" Arms and the Man (1894), Candida (1894 -95), You Never can Tell (1895-96) and "Three Plays for Puritans" The Devil's Disciple (1896-97), Ceasar and Cleopatra (1898), Captain Brassbound's Conversion (1899). The main objective of these plays was consideration of some significant social problems. In most of these early plays, Shaw the social propagandist was at work and, at his best. He was concerned mainly with such social problems as slum landlordism, capitalism, prostitution, jealousy, marriage and puritanical hypocrisy, which he treated most realistically and satirically with scintillating wit and humour. A general perception and belief of the literary world is that Shaw deals with the contemporary social problems not as a dramatist but as a socialist. The pen proved undoubtedly to be mightier than sword in Shaw's case. The way he wielded it with mighty ease earned him notoriety, the reputation of an agitator and a propagandist. However, a close study of the early plays of Shaw reveals that the dramatic artist is always lurking behind the social propagandist.

Shaw's maiden play, Widower's Houses, marks a major break from the English drama of eighties and dawns the beginning of a new kind of drama in England. It is a scathing attack directed at the social evils of slum landlordism and capitalism. The play, in Shaw's own words, is a "grotesquely realistic exposure of slum landlordism." (x-xi) Shaw shows how the despicable attitude and callous indifference to the sufferings of the poor on the part of the rich and their greed for more money resulted in the degradation of the poor. It is the double standards of the whole social system, which provokes Shaw to unveil it and show vice its own face. Shaw's Widower's Houses matches Ibsen's Ghosts for the general condemnation of its ruthless exposure of false idealism and pretentions.

Shaw succeeds in exposing the social problem of slum landlordism but at the same time seems to be lacking in play-craft. The play reflects the evils of slum landlordism and capitalism without any dramatic event. Furthermore it has no conflict which is an essentially ingredient of any good play. The play also seems to be different in human interest. The characters share the author's point of view and Cokane becomes his mouthpiece. Human interest seems to give way to discussion of economics. Nevertheless, what make the play interesting are the scenes of mirth replete with wit and humor. Any other dramatist writing on the theme of slum landlordism would have disheartened us with the cruelty and callousness of landlords and with realistically reported dull scenes of slum life. Shaw dismisses the landlords but irradiates his action with plentiful scenes of hilarity.

Shaw's chief interest in Mrs. Warren's Profession is to show that prostitution is caused not by female depravity and male licentiousness, but by undervaluing and overworking women who are forced to resort to prostitution, just to eke out their livelihood. As in Widower's Houses the people are held responsible for evils in society. It is a mature play, which shows at best, some of Shaw's powers as a dramatist. Shaw achieves dramatic conflict through the complexity of its theme and the economic and emotional aspects of the plot. 
Instead of being a direct attack against prostitution, the play gathers dramatic interest through the conflict between a mother and a daughter. Any other dramatist dealing with the theme of prostitution could have filled the play with pathos and plenty of sentimentalism, but Shaw blissfully declares that sentimentalism itself lies at the root of evil of prostitution.

Four of Shaw's early plays - The Philanderer, Arms and the Man, Candida, and You Never Can Tell deal with the social problems of love and marriage. The Philanderer is a satire on marriage as an institution involving economic slavery. It dramatizes grotesque sexual compacts made between men and women under marriage laws. It is also a satire on people's fake intellectual fads. Shaw's purpose in the play is to show that no woman is the property of a man and that she belongs to herself and nobody else. The play shows Shaw's progress over his earlier play in dramatic technique. The well-knit sub-plot concerned with Dr. Paramore emanates the best humour of the play. The depiction of the conflict between passion and reason lends the play dramatic interest. Conceived as an anti-romantic comedy, Arms and the Man shatters romantic idealization of love and war. Shaw strips war of its heroism and love of its romantic glamour through the creation of a "chocolate-cream soldier." Arms and the Man is important for illustrating the changes effected in the technique of play writing, especially the replacement of direct experience by indirect narration. Shaw fills the play with lighthearted banter, whimsicality and humour.

Candida dramatises the failure of a husband to understand his own life through the theme of the traditional triangle of love. The play has considerable artistic merit. Shaw artfully conveys his penchant for social satire through the story of a careless husband and impetuous lover. The play is a marvellous combination of dramatic situation and suspense with brilliant dialogue and social criticism. For the first time, Shaw is able to combine theme and technique without overemphasizing either. Like Pinero's The Weaker Sex, Shaw's You Never Can Tell dramatises conversion from intellectual pretensions to the realization of the biological needs of love and passion. Though dealing with love and passion, the play is totally free from the sentimentality, which pervades Pinero's play.

In the "Three Plays for Puritans" - The Devil's Disciple, Caesar and Cleopatra and Captain Brassbound's Conversion - Shaw attacks puritanical rigidity and narrowness of thought and outlook as well as the conceptual stereotypes underlying middle class morality. Each of these three plays presents a central character that is superior to religious moral systems, which prevail in the society of the day. They offer a fervent plea for humanism, which should replace Puritanism. It is highly unconventional persons like Dudgeon, Caesar, and Lady Cicely rather than the denominational men of religion like Anderson, God of Ra and Rankin who proved to be most human recalling the example of Christ. The "Three Plays for Puritans" in general and Caesar and Cleopatra in particular show Shaw at full command of his powers as a dramatist.

Thus, a study of Shaw's early plays written before 1900 AD reveals his dramatic powers in the earlier stages of development. His greatness as a dramatist before $1900 \mathrm{AD}$ lies in the fact that the themes of his plays are strikingly original. The influence of Ibsen, particularly in "Unpleasant Plays" is apparent. The early plays also show that Shaw is greatly influenced by contemporary native dramatists like Gilbert and Pinero. Shaw's greatness as a dramatist before $1900 \mathrm{AD}$ also lies in the Shavian outlook, which characterizes every play that he has written so far. Like Gilbert, Shaw gives his plays a typical personal touch.

There is a typical Shavian feel in each of his plays, so much so that, one can easily make out while reading, that it is a play of Shaw even without knowing about it. Unlike his predecessors and contemporaries, Shaw is clear in his thinking, steadfast in his tastes, and firm in his opinions. Shaw abandons the compromising attitude of Pinero and Jones in favour of a frank and fearless acceptance of facts. It is this unconventional, original approach to the problems of the contemporary society that distinguishes Shaw from the other dramatists.

It is noteworthy that certain social problems that Shaw presents in his early plays, receive greater attention in his later plays. The callousness of Dr. Paramore in The Philanderer is exhibited in greater measure in The Doctor's Dilemma. What Shaw preaches in Mrs. Warren's Profession, that the greatest of our evils and the worst of our crimes is poverty, he demonstrates in Major Barbara. The theme of conscience of Widower's Houses and Mrs. Warren's Profession is elaborated further in Major Barbara. In Widower's Houses, the clash is between Trench's conventionally held principles and the facts of ordinary life. In Mrs. Warren's Profession, it is between Vivie's honesty of purpose and her dependence upon her mother's ill-gotten income. In Major Barbara, it is caused by Barbara's scruples against accepting what she regards as tainted money for her Salvation Army work.

In Arms and the Man romantic love is contrasted with the practical love of a man of sense. In You Never Can Tell Valentine, the poor man, falls in love with the lovely Gloria, at first sight and has to tell her so, hating his helplessness. We have similar scenes in Shaw's later plays. For instance, in the love scene between Hypatia and Percival in Misalliance, the girl takes the initiative. In a later play, Heartbreak House, Shaw shows the attainment of conscious love in a girl who passes through emotional love and the love of convenience to spiritual union. 
An interesting observation is that some of the characters in the early plays of Shaw are developed in his later plays. For instance, the major characters that we come across in "Three Plays for Puritans" are those that exhibit the instinct of superhuman nature. Each of the three protagonists in the plays is distinguished by the quality of magnanimity. Dudgeon's heroic altruism, Caesar's clemency, Lady Cicely's inspired diplomacy - all affirm the possibility of transcending the petty motivation and limitations of ordinary human nature. These three extraordinary persons seem to be the precursors of Tanner in Man and Superman. It is a general perception of the literary world that Shaw is more of a thinker, a social reformer, a propagandist, and a literary satirist than a dramatic artist. In a way, Shaw himself has created this impression. He once said:

I am no ordinary playwright. I am a specialist in immoral and heretical plays. My reputation was gained by my persistent struggle to force the public to reconsider its morals. I write plays with the deliberate object of converting the nation to my opinion on sexual and social matters. I have no other incentive to write plays as I am not dependent on it for my livelihood. (83)

However, Shaw's statement needs to be taken with a pinch of salt. Though he is consciously only a social propagandist, Shaw is undoubtedly a dramatic artist unconsciously. The dramatic artist is always lurking behind the social critic. This can easily be perceived in the early plays of Shaw, which deal with the social evils eating into the vitals of the society of the day. Any other dramatist working on such social evils as slum landlordism, prostitution, and puritanical hypocrisy would have betrayed himself as a dramatic artist, depressing us with the naked exposure of such evils. But, the dramatic artist in Shaw intersperses his action with highly exhilarating scenes, the serious themes are dealt within such a light-hearted vein that the audience simply laugh, not always knowing that they are laughing at themselves or others.

Even from the point of characterization, the early plays of Shaw reveal his artistic skill. Characters like Mrs. Warren, Bluntschli, Candida, Marchbanks, Valentine, Gloria, Caesar, Dudgeon, and Lady Cicely are essentially convincing and human. His characters exist, not merely as his mouthpieces, but because he has something very serious and earnest to say through them. Regarding plot-construction too, Shaw's early plays reveal his dramatic powers. The plays like Mrs. Warren's Profession and Candida show how good Shaw is, in unifying a play into an organic whole. Shaw's critics shower special praise on the sub-plot of The Philanderer for its structural excellence. Furthermore, Shaw succeeds fairly well in his attempt to achieve dramatic conflict in most of the plays. On the whole, the early plays are suffused with dramatic interest while attacking the social evils of the day.

Again, Shaw's early plays are, more often than not, dismissed as prose pamphlets for discussing social problems that are outdated and dealing with the social evils that have ceased to be social evils today. In other words, a general notion is that the gross topicality of the plays comes very much in the way of our appreciation of them in modern times. It is true that Shaw's early plays deal with topical social problems some of which have already found a solution in the western society. All the same, we cannot possibly rule them out as irrelevant to modern times. Though some of the themes like slum landlordism are outmoded in the western world, they are of great relevance to India where such problems continue to plague the present day society.

Apart from the relevance of the themes to modern society, the plays have considerable dramatic interest as plays themselves. For Shaw, the manner in which a theme is treated is very important. He seems to be as much concerned with the artistic treatment of a social problem as its gravity. Even if the themes are outdated, Shaw's early plays are appealing to us by virtue of their art of characterization, brilliant dialogue, and animating prose and, above all, their sparkling wit and humour. This largely accounts for the perennial appeal of Shaw's plays.

Shaw was, above all, a dramatic critic who wrote about the stage, worked at the stage, thought intensely about it, and translated life as he observed it into stage terms. In this respect, he carved a niche for himself as one of the mammoth stage builders of the modern era. Like Socrates, Shaw was all-virtuous, allknowing and all-wise. He is undoubtedly an inveterate champion of the highest form of literature, oriented towards ethical purpose and a cherished life.

\section{References}

[1]. Gupta, P.C. The Art of Galsworthy And Other Studies. Allahabad: Vidyarthi Granthagar, 1963.

[2]. Joad, C.E.M. Shaw. London: Victor Gollangz, 1949.

[3]. Shaw, G.B. Preface. Plays Unpleasant. London: Penguin, 1946. 